\title{
Italian Golden Shares - a Never-Ending Story?
}

\author{
Jelena Ganza \\ PhD candidate, Dickson Poon School of Law, King's College London
}

The obligation of sincere co-operation[i] of all Member States of the European Union entails, inter alia, the national governments to comply with judgements of the Court of Justice of the European Union (CJEU) and adjust national measures accordingly. Timely and appropriate compliance initiatives would be seen as acting in good faith and in line with the sincere cooperation principle. Persistent non-compliance with judgements remains a problem and it particularly arises in cases where national governments' influence over former strategic stateowned enterprises (SOEs), such as the largest Italian energy/oil company ENI, the former state telecommunication monopoly Telecom Italia and dominant electricity giant ENEL, is at stake.

This non-compliance stems from the basic conflict between the liberalisation aims of the Union and egoistic interests of certain Member States, which sought to retain influence over strategic industries by employing specific Control Enhancing Mechanisms called 'golden shares'. Golden shares are the special class of shares introduced for the sole benefit of the 'former owner' - the state. These mechanisms aim at enhancing governmental control after privatisation, thus protecting important industries from turbulences of the free market. A typical golden share could have the following structure: where direct influence was lost due to privatisation, special powers, such as the power to veto the usage and disposal of strategic assets and the right to appoint directors, is attached to the golden shares held by the state.

These mechanisms are eagerly employed by the Member States' governments and ever so eagerly battled by the European Commission and the CJEU. Golden shares are illegal, unless justified by overriding public interest and the necessity to protect public security, are legally certain, appropriate and non-discriminative. [ii] The justification criterion is narrow, however some governments were not only willing to face the CJEU, but were also determined to continue using already overruled golden shares post-judgement. Such tactics allow the matters to drag, contributing to a free-rider problem, which in turn means acting in bad faith and contrary to the principle of sincere co-operation, thus causing obstinate non-compliance and undermining the authority of the CJEU.

There are fifteen cases that relate to golden shares and only in one of them the use of these measures has been justified. [iii] After the condemning judgement is passed, the Member State in question is obliged to comply without delay and either to severely restrict its golden shares or to repeal them altogether. Taking into account the success rate on justifying golden shares, it could be ascertained that following a condemning judgement the Member State in question is obliged not to try and amend but repeal them, since passing the justification test is a challenging task. Some Member States have disclosed a remarkable persistence in noncompliance alongside the determination to retain golden shares in spite of condemning judgements and looming sanction threats. Italy could be seen as one of such examples of persistent bad-faith compliance with four cases upon it, three of which relate to obstinate golden share Decree-Law No.332/1994. [iv] Italian authorities have not addressed judgements 
in good faith and the same golden share measures were effective for more than a decade postjudgement.

The first ruling on golden shares has been on Italian Decree-Law No.332/1994, which governed privatisation of SOEs. [v] Article 2 of the Decree-Law prescribed the implementation of further decrees which would create a golden share in certain strategic companies. The Decree-Law No.332/1994 did not infringe the Treaty by itself, as it merely empowered certain authorities to 'activate' it by further company-specific decrees, stating which company shall be protected and how. Since the Decree-Law does not infringe the Community law per se - as long as the exercise of golden shares (laid down in further decrees) passes the justification test - it becomes 'untouchable' in a way that it allows for a numerous amendments to 'activating' decrees. If golden shares ought to be found applied in unjustified manner, the ways in which they are applied could be changed, without the necessity to change the Decree-law itself. The conditions for exercise of golden shares, or more precisely - their absence, have become the subject of the CJEU's judgement on case $C$ 58/99 in which the Commission sued Italy under what is now Article 258 TFEU. In 2000, in absence of any justifications, the CJEU found that the application of golden has been illegal. Even though the Italian government has expressed its willingness to comply prior to the judgement, no adequate amendments were undertaken following the condemning ruling.

The amendments which aimed at justifying the golden shares at stake were transposed into Article 66 of Financial Law No. 488 of 23 December 1999 and the 'activating' decree of 11 February 2000. [vi] This compliance measure aimed to provide a detailed explanation under which circumstances and how the GSs of the Decree-Law No.332/1994 should be executed, but failed to do so. These amendments were of declamatory character as they were merely repeating the requirements of the justification, while failing to specify what precisely the circumstances for their exercise are. This in turn retained the possibility of further disputes over legality of golden shares, which inevitably followed. The compliance initiative of Article 66 Financial Law No.488/1999 acted as a smoke screen dispersing the attention from active golden shares. Acting in good faith would entail the Italian government, first and foremost, to abstain from vague and inadequate justification attempts which delayed final compliance as well as to abstain from implementation of new golden shares. Nonetheless, in 2001 following the condemning judgement on case $C-58 / 99$, the Italian government implemented another golden share Decree-Law No.192/2001, which has been overruled by the CJEU in case $C-174 / 04$. [vii] In that case the Italian government tried once again to fiddle with the golden share amendments, but after being threatened with sanctions under Article 260 TFEU it has fully abrogated contested provisions in 2006. Italian authorities have complied with the judgement on case $C-174 / 04$ but it took one unsuccessful amendment and potential of application of penalties to achieve this.

As for the first Italian case on golden shares $C$-58/99, the Article 2 of Decree-Law No.332/1994 became subject of the CJEU's preliminary ruling in Federconsumatori and later in judgment on case $C$-326/07. In 2007 the CJEU has once again pointed on the incompatibility of the Decree-Law No.332/1994 with the Community law in Federconsumatori, confirming the obstinacy of the golden shares. In this case the golden shares emerge in a newly amended format after yet another justification attempt via the new Article 4(227) to (231) Law No.350 of 24 December 2003 and implementing Decree of 10 June 2004.[viii] This justification attempt emerged as a legislative answer to the Commission's formal letter sent in February 2003, a second action under Article 258 TFEU on the Decree-Law No.332/1994. The Italian authorities undertook to introduce new amendments by the end of 2003. The Law No.350 of 24 December 2003 was implemented in 
time. However, it did not contain justifications, but merely created a platform for subsequent justification, by further Decree of 10 June 2004. However, the latter amendments were also insufficient to justify the use of golden shares. The new provisions of Law No.350 alongside the Decree of 2004, have limited golden shares and introduced justifications based on 'real and serious risk' without specifying what exactly constitutes such risk.

These amendments became subject of the second condemning judgment of the CJEU in 2009 on case C-326/07. Since compliance did not follow and no drafts were submitted for a review, the Commission proceeded with sanction-threats under Article 260 TFEU. On 20 May 2010 Italy's then Prime Minister Berlusconi has issued a decree which aimed at addressing the Commission's concerns and the Court's ruling(s) by amending the criteria for execution of special powers laid down in 'activating' Decree of 10 June 2004. ix] The compliance measure of Berlusconi's Decree appears to be even more controversial, as it comprised of just one Article that in turn comprised of a single sentence which repeals contested justifications of Decree 10 June 2004! [x] Berlusconi's Decree repeals Article 1(2) of the Decree (the one that laid down the criteria for exercise of special powers of DecreeLaw No.332/1994 and has been overruled by the CJEU in case $C-326 / 07)$. By eliminating the sole justifications of exercise of golden shares Berlusconi has 'addressed' the judgment. The only justification of special powers has now been repealed and this 'compliance initiative' does neither justify nor eliminate golden shares as such. Berlusconi's Decree of 20 May 2010 appears to be a misleading measure that only aimed at further procrastination, acting as another smoke screen.

On 16 February 2011 the Commission has started the second stage of infringement proceedings and issued a reasoned opinion urging Italy to comply. During that time the Italian government has been going through one of the most difficult economic and political situations in its modern history: the European Debt crisis. It has been a 'lucky co-incidence' that the need to adopt new golden share amendments has co-incised with some radical changes within the Italian government. Berlusconi and his government had to resign on 12 February 2011 while the new 'technocratic' government had to be formed in order to implement severe austerity measures. A new Prime Minister has been formally appointed Mario Monti, the former EU Competition Commissioner, known for his tough stance on proEuropean integration and competition enhancement. The technocratic government would stay in office until the elections in April 2013. By that time several 'unpopular' economic and social reforms have to be introduced and new provisions on golden shares would fall within that scope.

After more than a decade of procrastination, the Italian government seems to have finally addressed the issue of golden shares overruled back in 2000 by significantly amending the original provisions by new Decree-Law No.21 of 15 March 2012. [xi] This new Decree-Law No.21/2012 establishes a notion of 'strategic assets' which are subject to golden shares and introduces a 'fit-and-proper' test for potential investors who seek participation in control of strategic companies. The golden share provisions now appear to have a considerably narrower scope of application and increased legal certainty. But yet again, the contested golden share provisions have been amended, not repealed, which in turn has the potential to be incompatible with the EC law. The Commission is currently analysing new provisions and awaits the implementation of the 'activating' Decrees which would further establish the conditions for the applications of golden shares. Whether or not Italy has finally complied with both golden share cases $C-58 / 99$ and $C$-326/07 remains to be seen, while the battle for illegal golden shares continues, and state-driven protectionism is on the rise due to economic crisis. 
[i] The obligation of sincere co-operation has been previously enshrined by the Article 5 of the Treaty of Rome, then became Article 10 EC and has been in principle replaced by 4(3) TEU which states: 'Pursuant to the principle of sincere cooperation, the Union and the Member States shall, in full mutual respect, assist each other in carrying out tasks which flow from the Treaties. The Member States shall take any appropriate measure, general or particular, to ensure fulfilment of the obligations arising out of the Treaties or resulting from the acts of the institutions of the Union. The Member States shall facilitate the achievement of the Union's tasks and refrain from any measure which could jeopardise the attainment of the Union's objectives.'

Criminal proceedings against Sanz de Lera and Others (C 163, 165 \& 250/94), 14 December 1995, paras. 23-28, the Commission accepted that fundamental freedoms may be restricted by national measures justified on grounds of public policy, public security or public health or by overriding reasons in the public interest, but only in so far as there is no Community harmonising legislation providing for measures necessary to ensure the protection of the fundamental interests of the State. These measures have to meet the requirement of legal certainty and proportionality, see also the Court's judgement Commission v Italy, C-326/07 of 26 March 2009, at para. 14; Commission v Portugal, C$367 / 98$, judgement of 4 June 2002, at para 48;

[iii] Commission v. Italy, C-58/99, judgment of the CJEU of 23 May 2000; Commission v. France, C-483/99, 4 June 2002; Commission v. Belgium, C-503/99, 4 June 2002 (justified); Commission v. Portugal, C-367/98, 4 June 2002; Commission v. United Kingdom, C-98/01, 13 May 2003; Commission v. Spain, C-463/00, 13 May 2003; Commission v. Italy C-174/04, 02 June 2005; Joined cases C-282/04 and C-283/04, Commission v. Netherlands, 28 September 2006; Federconsumatori v. Commune di Milano, C-463/04 and C-464/04, referred to the Court for preliminary ruling, 6 December 2007; Commission v. Germany, C-112/05, 23 October 2007; Commission v. Spain, C-274/06, 14 February 2008; Commission v. Spain, C207/07, 17 July 2008; Commission v. Italy, C-326/07, 26 March 2009; Commission v. Portugal , C-171/06, 8 July 2010; Commission v. Portugal, C-543/08, 11 November 2010

[iv] (Italian Privatisation Law as amended), Decreto del Presidente del Consiglio dei Ministri, definizione dei criteri di esercizio dei poteri speciali, di cui all'art. 2 del decreto-legge 31 maggio 1994, n. 332, convertito, con modificazioni, dalla legge 30 luglio 1994, n. 474; Decree-Law No 332 of 31 May 1994 (GURI No 126 of 1 June 1994), converted, after amendment, into Law No 474 of 30 July 1994, (GURI No 177 of 30 July 1994)

Decreto del Presidente del Consiglio dei Ministri, definizione dei criteri di esercizio dei poteri speciali, di cui all'art. 2 del decreto-legge 31 maggio 1994, n. 332, convertito, con modificazioni, dalla legge 30 luglio 1994, n. 474; Decree-Law No 332 of 31 May 1994 (GURI No 126 of 1 June 1994), converted, after amendment, into Law No 474 of 30 July 1994, (GURI No 177 of 30 July 1994)

[vi] The original text of the Art.66 of Financial Law No 488/1999 (LEGGE 23 dicembre 1999, n.488, Disposizioni per la formazione del bilancio annuale e pluriennale dello Stato (legge finanziaria 2000) could be found in Italian at: http://www.normattiva.it/urires/N2Ls?urn:nir:stato:legge:1999;488 Gazzetta Ufficiale, n. 302 del 27-12-1999, for 
Implementing Decree of the Prime Minister 11/02/2000 see

\section{http://gazzette.comune.jesi.an.it/2000/40/5.htm}

[vii] The law titled 'Urgent provisions to ensure the liberalisation and privatisation of specific public service sectors', GURI No 170 of 24 July 2001, published in Italian Official Gazette No 120 on 25 May 2001, the original text could be found at: http://www.normattiva.it/urires/N2Ls?urn:nir:stato:decreto-legge:2001;192,

Gazzetta Ufficiale No 299 of 27 December 2003 and Gazzetta Ufficiale No 139 of 16 June 2004

[ix] Decreto Del Presidente Del Consiglio Dei Ministri (DPCM) 20 maggio 2010 (published in Italian Official Gazette n.117 del 21-5-2010 ) (10A06506)

x] Decreto Del Presidente Del Consiglio Dei Ministri 20 maggio 2010 (published in Italian Official Gazette n.117 del 21-5-2010 ) (10A06506)

Decreto-Legge 15 marzo 2012, n. 21 Norme in materia di poteri speciali sugli assetti societari nei settori della difesa e della sicurezza nazionale, nonche' per le attivita' di rilevanza strategica nei settori dell'energia, dei trasporti e delle comunicazioni. (12G0040) (published in Italian Official Gazette n.63 del 15-3-2012) 